\title{
Roque de Barros Laraia Entre a Antropologia e o Indigenismo: Reflexões sobre uma Trajetória
}

\begin{abstract}
Edilene Coffaci de Lima e Bacharel em História pela UFMG, Roque de Barros Laraia integrou a primeira turma do M árnio Teixeira Pinto Curso de Especialização em Antropologia Social do Museu Nacional, em 1960. Desde então, dedicou-se integralmente à Antropologia, em particular à Etnologia Indígena. Aluno de Roberto Cardoso de Oliveira e, mais tarde, de Florestan Femandes, Roque Laraia procurou em seus estudos analisar tanto a relação entre índios e brancos (como em índios e Castanheiros, escrito em parceria com Roberto Da Matta) quanto a organização social e a cosmologia ameníndia (como em Tupi: índios do Brasil atual). Professor Aposentado da UnB após quarenta anos de vida acadêmica, Roque Laraia assumiu, durante nove meses do ano passado, a Diretoria de Assuntos Fundiários (DAF) da Fundação Nacional do Índio (FUNAI). Nesta entrevista, realizada em Curitiba após uma breve conversa em Petrópolis, durante a XIV Reunião da Associação Nacional de Pós-Graduação em Ciências Sociais (ANPOCS), da qual é atualmente presidente, Roque Laraia falou sobre sua trajetória acadêmica e sua atuação na política indigenista.
\end{abstract}

Campos: Gostaríamos que o senhor começasse falando sobre como se aproximou da Antropologia e, em particular, da Etnologia. Como chegou a participar dos projetos "Estudo de Áreas de Fricção Interétnica" e "Estudo Comparativo de Organização Social de Grupos Tribais Brasileiros", ambos dirigidos pelo Professor Roberto Cardoso de Oliveira?

Roque Laraia: Vou começar um pouquinho antes disso. Por que eu fui para a Antropologia? Na verdade eu era estudante de História na UFMG, que formava bacharéis, em 1959. Naquele momento eu não tinha nenhum interesse em Antropologia, porque eu fui um dos últimos alunos de um professor de Antropologia da UFMG que era muito citado por ser muito ruim. Acho que foi uma reação: eu comecei a procurar livros de Antropologia para saber o que era Antropologia. De qualquer maneira, eu nunca pensei na perspectiva de fazer Antropologia, exatamente porque ignorava tudo sobre o assunto. No verão de 
1960 eu estava em férias e, não sei porque, passei na Faculdade de Filosofia e tinha um anúncio de um curso de pós-graduação em Antropologia no Museu Nacional. Pós-Graduação no sentido de especialização, não stricto sensu, porque era um curso de um ano, dirigido pelo Roberto Cardoso de Oliveira, e que oferecia seis bolsas e eram seis vagas. A prova era como continua sendo hoje, tinha um trabalho prático, em que se escrevia sobre alguma coisa, fazia-se uma análise. Quando eu vi o anúncio, já estava em cima do prazo e eu tinha um trabalho escolar sobre Congado, um ritual afro-brasileiro. Eu peguei aquele trabalho, dei uma caprichada nele, fiz a inscrição e acabei sendo selecionado. Bem, aí todo mundo já sabe... Os selecionados foram eu, Roberto da Matta, Alcida Ramos, Edson Diniz, Hortência Caminha e Odília Benvenucci. Estas duas últimas foram as pessoas que não continuaram na Antropologia. Nunca me passou pela cabeça escolher outra coisa além da Etnologia. Para mim Antropologia era Etnologia - mesmo porque na história da Antropologia brasileira a Etnologia sempre teve uma presença muito forte. O curso foi um curso de três meses de seminários intensos com o Roberto, eram oito horas diárias de aplicação ao curso. Eu ainda tinha uma dificuldade adicional porque sabia muito pouco inglês e todos os textos eram em inglês. Ao mesmo tempo que eu fui aprendendo Antropologia, fui aprendendo inglês. Tinha que levar os textos para casa e ficar consultando o dicionário. Este não era o caso do Matta e da Alcida, que já falavam inglês. O fato é que no final destes três meses teve uma pesquisa de campo. Inicialmente haveria duas pesquisas: iria um grupo para o Nordeste, trabalhar com sociedades camponesas, e o outro grupo iria para os Terena. Iriam três alunos para cada lado, mas isso não deu certo, não sei quais foram os motivos. Acabou indo todo mundo com o Roberto para os Terena. Meu primeiro contato com índio foi com os Terena. Andando com o Roberto, nós paramos na rua em Campo Grande e ele começou a conversar com um japonês, de óculos rayban. Quando se despediu, a gente perguntou para ele: "Quem é esse japonês?" O Roberto respondeu: "J aponês coisa nenhuma!" A gente confundiu japonês com Terena, porque estava de calça jeans e de óculos. Enfim, era um Terena urbanizado, um desses que viviam na periferia de Campo Grande e Aquidauana.

Campos: Nesta época o Professor Roberto já havia estudado os Terena?

Roque Laraia: Ele tinha estudado os Terena na aldeia, o que resultou no primeiro livro dele, $O$ processo de assimilação dos Terena. O material desta pesquisa de que eu estou falando resultou num outro livro, Urbanização e tribalismo. Foi um treinamento intenso. Como éramos três homens 
e três mulheres, formávamos três casais. Cada casal ia para um canto, a cidade foi dividida. Fizemos um censo dos Terena ao mesmo tempo em que discutíamos questões culturais. À noite tínhamos que escrever e fazer a leitura do diário. Todo mundo lia seus diários e o Roberto comentava. Foi um treinamento bem pesado. Tinha uma colega que, para se destacar e escrever mais, tomava um remédio para ficar acordada e escrever de madrugada. Acabou passando mal. Já havia uma competição. Mesmo porque, naquele momento, começou a surgir a idéia de que algumas pessoas poderiam ser contratadas pelo Museu Nacional. Quando voltamos fomos elaborar todo este material. Isso também foi parte do treinamento, porque conseguimos transformar todas aquelas entrevistas e os diários em dados e tabelas.

Campos: O Roberto Cardoso de Oliveira era o único professor do curso naquela época?

Roque Laraia: Para falar a verdade, era. Ele tinha um assistente chamado Osmar Montenegro, mas o assistente tinha uma participação muito pequena no curso. O máximo que podia acontecer era que o Roberto, às vezes, convidava palestrantes. O Castro Farias de vez em quando fazia uma palestra. Ou alguém que passava pelo Rio fazia uma palestra. Nós líamos muito. O único livro de Antropologia traduzido no Brasil era o do Ralph Linton, O Homem. Não tinha mais nada em português. Por sorte, naquele ano, saiu traduzido em português o W. Goode e P. Hatt, Método em pesquisa social. O tempo todo a bibliografia era em inglês ou francês. No final do ano teve uma prova e nessa prova houve uma classificação. Fazia muito tempo que o Museu não contratava ninguém e resolveu contratar os três que tinham a maior nota na prova: a Alcida, o Matta e eu. Mas dos três que foram selecionados, só eu e o Matta fomos contratados, porque descobriram que a Alcida era portuguesa. Naquele tempo era regime estatutário e estrangeiros não podiam ser contratados. Com isso a Alcida acabou indo para Wisconsin fazer o doutorado.

Campos: Para onde foi o Edson Diniz?

Roque Laraia: O Edson Diniz voltou para Belém, ele era de lá, trabalhava com o Eduardo Galvão. De certa forma o Galvão tinha enviado o Edson para fazer esse curso e ele voltou para Belém. Anos depois ele foi para Marília, no estado de São Paulo. Bom, mas estou perdendo o fio... Por que Antropologia? Enquanto estava fazendo o curso, estava convencido de que era aquela Antropologia que eu queria, tinha descoberto aquilo que eu não consegui descobrir na História. É muito interessante que em toda a minha geração ninguém fez Ciências Sociais. O Roberto da Matta fez História, o Melatti fez História e Geografia (era assim o curso lá em Petrópolis), a Alcida 
fez Geografia e o Roberto Cardoso fez Filosofia. Eu não saberia dizer quem foi o primeiro antropólogo originário desse grupo que fez Ciências Sociais. Uma grande parte dessa geração mais antiga fez História ou Geografia. Mas, por que a Etnologia? Para mim Antropologia era Etnologia. Acho que foi só no final da década de 1960 que se foram delineando várias Antropologias, não só uma antropologia indigenista. Também porque o espaço em que a gente trabalhava era o Museu Nacional, a Antropologia do Museu era dedicada aos índios. Quando surgiu o PPGAS é que deixou de ser, os professores começaram a fazer outras coisas.

Campos: Da pesquisa com os Terena até chegar aos Suruí e Asurini, o que o senhor fez no intervalo?

Roque Laraia: No segundo semestre de 1960 a gente começou a definir o objeto de pesquisa: começamos a buscar qual seria o grupo indígena que iríamos estudar. Pouca gente sabe disso, mas eu me interessei por Fulniô e comecei a ler Max Boudin, Estevão Pinto e todos aqueles que tinham passado pelos Fulniô. Hoje eu fico muito contente de não ter ido.

Campos: Por alguma razão particular o senhor não foi aos Fulniô?

Roque Laraia: Um dia apareceu lá no Museu um frei dominicano, o frei Gil Gomes, dizendo que tinha descoberto uma tribo no Pará, que eram os Suruí, um grupo recém-contatado. Os Suruí foram contatados em 1960 e eu fui para lá em 1961. O frei Gil participou da atração deles desde 1951, mas todas as vezes que ele se aproximava da aldeia, os índios sumiam. Em 1960, finalmente, em função do contato com os caçadores de pele, os Suruí pegaram uma enorme epidemia e logo eles foram contatados. Aí eu resolvi ir para lá.

Campos: Entre os Fulniô e os Suruí...

Roque Laraia: Eu preferi os Suruí. É aquela história, e eu ouço isso até hoje, que entre os índios 'bonitos' e os 'feios', por que eu iria ficar com os 'feios'? Essa foi a conversa que eu ouvi na FUNAI o tempo todo. Quando chegavam os Fulniô, os Xavante falavam: "Chegaram os sem-terra!" Entre ir para o Nordeste e ir para a floresta amazônica, fiquei com a segunda alternativa. Preferi um grupo sem contato, sobre o qual ninguém havia escrito. E também, por outro lado, o Roberto da Matta já estava pensando em ir para os Gaviões. Naquele momento eu comecei a estudar a literatura Tupi-Guarani. 
Campos: Como foi que os Assurini entraram na pesquisa iniciada com os Suruí?

Roque Laraia: Desde que eu fui para os Suruí, comecei a ouvir falar de um outro grupo. Os Suruí sempre falaram que outros haviam ficado no mato, que tinham outros companheiros. A gente tinha uma dificuldade enorme de comunicação. Ninguém conseguia falar o português, tinha só um ano de contato. Havia um garoto que falava português, que aprendeu rapidamente. Então eu trabalhava com um intérprete que tinha de 10 ou 12 anos. Em um dado momento eu comecei a acreditar que havia um outro grupo no mato. Em outros momentos pensava que todos aqueles que eles falavam eram já mortos. Aí comecei a receber notícias de um grupo que tinha aparecido em Tucuruí, eram os Assurini. Em 1961 fui aos Suruí e em 1962 aos Assurini. Realmente os grupos são iguais: os dois têm os mesmos rituais e a língua é muito parecida. Eu tinha feito o levantamento de muitas genealogias entre os Suruí - estes Tupi-Guarani são muito bons para fornecer genealogias, eles dão várias gerações -, mas não cruzavam com as genealogias Assurini como eu queria. Eu imaginava que chegaria um momento em que um antepassado de um seria o antepassado do outro, indicando uma fissão. Anos depois eu publiquei um artigo chamado "Etnohistória Tupi" em que eu levanto esta hipótese de um grupo Tupi, chamado Tocantins, que entrou em contato com os portugueses, com os europeus - não tem nenhuma referência histórica não, é só especulação - e que se fragmentou em vários grupos que são muito parecidos. Todos aqueles grupos que vivem entre o Xingu e o Tocantins - Suruí, Assurini do Trocará, Assurini do Xingu, Parakanã e Araweté - seriam o resultado de um processo de fissão. Teria sido uma estratégia de sobreviver ao contato, dividindo os grupos, cada um foi para um lado e criou aquilo que é a metáfora que eu usei para falar de "variação de um mesmo tom". Estes grupos são sempre a mesma coisa, com ligeiras diferenças. Talvez o mais diferentes de todos seja o Araweté.

Campos: De qualquer maneira, estes seus trabalhos iniciais estavam vinculados a questões dos projetos do Professor Roberto Cardoso de Oliveira, que já apontavam para essa possibilidade de incorporar as populações do Nordeste.

Roque Laraia: Já apontavam. Nesse momento o Roberto já tinha uma interação muito grande com o David Maybury-Lewis. O David, num determinado momento da vida, teve um interesse muito grande pelo Nordeste, tanto é que ele foi para o Nordeste, passou anos no Recife. Então, quando o PPGAS surgiu, o David e o Roberto criaram o projeto Museu Nacional - Harvard Brazil Central, mas tinha um ramo que era o Nordeste. Neste momento eu já estava em Brasília. Se você 
pegar a primeira turma de mestres do Museu Nacional, verá que tem um grupo que foi para o Brasil Central - Cláudia Menezes, Otávio Velho e outros - e uma turma que foi para o Nordeste. Houve uma divisão. Mas os dois projetos em que eu trabalhei - o de Fricção Interétnica e o de Organização Social - eram sobre índios. Desde que a gente chegou no Museu o Roberto já trabalhava com isso. O Roberto tinha uns fichários e nós ficávamos lá preenchendo, regras de parentesco e descendência e tal, de vários grupos. Nesta época já tinha sido publicado o livro de George P. Murdock, Social Structure, que fazia um inventário de grupos do mundo inteiro, classificados em onze tipos de organização social. Quando eu preenchia formulários do tipo do Murdock, os dois (Suruí e Asurini) eram exatamente iguais. Aí você vai ver um grupo e vai ver o outro... Aí surgiu uma metáfora, como se fosse um tipo de relógio: as peças são iguais, mas o funcionamento é diferente.

Campos: É nessa época que se discute a "anomalia apinaye", à qual Roberto da Matta vai se dedicar? Roque Laraia: Exato, mas a "anomalia apinaye" é uma coisa mais antiga. Quem criou a "anomalia apinaye" foi o diálogo entre o Nimuendaju e o Lowie. De repente chegou-se a um grupo de descendência paralela, que na teoria é possível mas na prática não foi encontrada. O exemplo era o modelo apinaye. Um bando de gente começou a escrever sobre isso, até que o Matta foi lá e resolveu o problema.

Campos: Estas questões já faziam parte do "Projeto Comparativo de Organização Social"? Roque Laraia: Isso aí fazia parte do projeto seguinte, com o David Maybury-Lewis, sobre as populações J ê do Brasil Central. Os dois representantes brasileiros eram o Matta e o Melatti. Como estrangeiros tinha o Terence Turner, J ean Bramberg, J ean Lave, Dolores Newton, J. C. Crocker e outros.

Campos: Suas preocupações comparativas faziam parte do projeto de organização social? Roque Laraia: Faziam parte. Na verdade a gente fez uma pesquisa com duas entradas. A gente tanto colhia material para estudar organização social, no "Projeto Comparativo", quanto também para o "Projeto de Áreas de Fricção Interétnica".

Campos: As duas preocupações não estavam efetivamente separadas?

Roque Laraia: Estavam na nossa cabeça, porque nosso objetivo era escrever uma grande monografia, como fizeram Malinowski e Radcliffe-Brown, uma monografia que falasse sobre os índios. Mas nós descobrimos que isso não existia, os trobriandeses viviam numa ilha. Aqui você tinha castanheiro, caçador, tinha as frentes de expansão da sociedade brasileira. De certa forma o 
Roberto foi aluno do Darcy Ribeiro. Não o aluno formal, afinal o Roberto fez filosofia na USP. Mas depois ele conheceu o Darcy e foi para o Rio de J aneiro, trabalhou no Museu do Índio. Então o Darcy, de certa forma, orientava o trabalho do Roberto, e o Darcy já tinha toda aquela preocupação com as frentes de expansão da sociedade nacional. Era esse esquema praticamente que a gente usava. Só que o Roberto introduziu a idéia de que você não podia estudar um grupo indígena sem estudar a frente de expansão que estava em contato.

Campos: Avançando um pouco, como foi ter trabalhado no doutorado sob a orientação do Professor Florestan Fernandes?

Roque Laraia: Meu interesse em trabalhar com o Florestam veio do fato de que ele tinha escrito dois livros sobre os Tupi, que são A Organização Social Tupinambá e A Função Social da Guerra na Sociedade Tupinambá. Numa entrevista que o Florestan Fernandes deu à Mariza Peirano, ele disse que são os dois melhores livros que ele escreveu na vida, embora ele seja conhecido como um grande sociólogo. No doutorado eu estava interessado em fazer um estudo comparativo da organização social e meu modelo era, de certa forma, a organização social dos Tupinambá. Em vez de fazer o doutorado em Antropologia, eu fiz doutorado na Sociologia. Naquele tempo vigorava na USP o regime das cadeiras (cátedras). Na cadeira de Antropologia estava o Egon Schaden e na de Sociologia estava o Florestan. Eu senti que tinha mais afinidade com o Florestan e fui fazer o doutorado com ele. Na verdade, tive pouca orientação, porque era uma época conturbada e o Florestan acabou sendo cassado e aposentado. Então ele pediu para que o Luiz Pereira fosse meu orientador. O Luiz Pereira aceitou fazer o papel de orientador e presidir a banca, mas avisou que não entendia nada a respeito de índios. A pouca orientação que eu tive foi do Florestan. Quando eu defendi a tese o Luiz Pereira presidiu a banca, era uma banca só de antropólogos, e eu fiquei muito honrado porque o Florestan foi pela primeira vez na USP - primeira e uma das poucas vezes - depois de ser cassado, para assistir à minha defesa de tese.

Campos: Quem fazia parte da banca?

Roque Laraia: A banca era Thekla Hartmann, J oão Batista Borges Pereira, Roberto Cardoso de Oliveira e o recém-doutor que era o J úlio César Melatti.

Campos: Nessa época sua preocupação era exclusivamente com organização social?

Roque Laraia: Naquele tempo eu acho que tinha três preocupações: organização social e parentesco 
de um modo geral, cosmologia e o contato entre índios e brancos. Acho que durante muito tempo eu mantive essas três preferências.

Campos: Quais eram seus interlocutores mais próximos?

Roque Laraia: Eu conversava com o Melatti e com o Matta. Não conversava com a Alcida porque ela estava nos Estados Unidos. De interlocutores que estudavam Tupi eu tinha o Eduardo Galvão, mas era difícil encontrá-lo porque ele ficava em Belém. Havia outras pessoas que estudavam Tupi, mas que estavam longe: o Wagley, em Columbia, o Robert Murphy, que eu nunca encontrei, e o Watson, que tinha estudado os Guarani. Mas no Brasil era o Galvão. O Galvão fez o doutorado em Columbia, é o primeiro PhD brasileiro em Antropologia, mais ou menos em 1949. Eu estou me esquecendo, mas havia uma outra pessoa com a qual eu tinha pouco contato, porque era também uma pessoa mais velha, que era o Herbert Baldus, que estudou os Tapirapé. Quando publiquei Índios e castanheiros eu mandei um volume para ele, com dedicatória. Anos depois, quando ele morreu, o J oão Batista [Borges Pereira] me devolveu com as anotações do Baldus.

Campos: Saindo um pouco da Etnologia, o senhor escreveu também um artigo sobre o chá-depanela e um outro sobre o Éden. Como estes artigos entram no conjunto de suas pesquisas?

Roque Laraia: O artigo sobre chá-de-panela foi decorrência de meu trabalho como professor de graduação. Em Brasília a gente sempre deu aula na graduação e na pós-graduação. Na disciplina de Antropologia Cultural eu costumava dar um pequeno trabalho e uma aluna, a Maria Zaira Batista de Mello, fez um trabalho que eu achei muito inteligente. Na verdade eu assino o artigo com ela, mas a pesquisa quem fez foi ela. Eu nunca tive muito interesse em estudar gênero. Quanto ao artigo sobre o Éden, há alguns anos eu fiquei intrigado sobre quem era Lilith. Fui na Enciclopédia Britânica e só dizia o seguinte: primeira mulher de Adão, expurgada da Bíblia. Sem nenhum afinco, eu nunca me dediquei a isso, eu comecei a procurar informações. Toda vez que eu podia, tinha alguma oportunidade, eu ia descobrindo coisas. Fiz contato com pessoas que conheciam materiais judaicos, que começaram a coletar informações para mim, a me dar indicações. De repente eu descobri que a coisa era mais séria, porque a "patrona" (melhor seria, a "matrona") do movimento feminista americano era Lilith. Achei que dava alguma coisa interessante e publiquei na Revista de Antropologia da USP. Eu descobri uma história interessante. Durante muitos anos o Conselho Indigenista Missionário promovia uma série de palestras. A partir do dia em que eu citei 
Lilith, nunca mais me convidaram. Freiras e bispos presentes nessa palestra ficaram perplexos, porque nunca tinham ouvido menção a Lilith.

Campos: O senhor tinha também um interesse paralelo em estudos sobre negros.

Roque Laraia: Eu escrevi um artigo chamado "Relações Raciais no Brasil". Como éramos poucos em Brasília, nós dávamos muitos cursos. Então eu me preparei para dar um curso sobre a questão racial. Da mesma forma que a gente no curso de Introdução à Antropologia em Brasília tinha uma parte substancial sobre evolução biológica, que hoje não tem. De vez em quando eu vejo antropólogos que demonstram que desconhecem completamente o assunto. Uma vez estava uma doutora em Antropologia no México e lá nas pirâmides ela disse: "Os astecas surgiram aqui". Eu acho que um antropólogo tem que ter uma noção mais generalista, para não correr aquele risco que o Castro Farias sempre brincava lá no Museu Nacional, "esses antropólogos que só querem dar cursos sobre os seus mestrados".

Campos: Estes seus outros artigos são todos então sistematizações de leituras de cursos que ministrou na graduação?

Roque Laraia: São, são conjunturais.

Campos: Voltando agora aos índios, em particular à atuação indigenista. Antes que discutíssemos a sua passagem recente pela FUNAI, gostaria que o senhor falasse da convivência com antropólogos que estiveram no SPI ou na FUNAI, como o Eduardo Galvão, Darcy Ribeiro e Roberto Cardoso de Oliveira. O senhor esteve próximo destas pessoas e recentemente esteve trabalhando na FUNAI. Quais as diferenças mais significativas entre estes dois períodos, tanto em termos institucionais quanto em relação à atuação dos próprios índios?

Roque Laraia: Desde o início, desde que a ABA foi fundada, os antropólogos adotaram como causa principal a questão indígena. Tanto é que durante muitos anos os antropólogos se preocuparam com os índios e a questão negra, que do ponto de vista demográfico tem muito mais repercussão, ficou na seara dos sociólogos. Só em época mais recente é que nós vamos ter antropólogos tratando da questão dos negros. Então, desde aquele momento em que a gente viveu a situação de contato, situações dramáticas... Eu cheguei nos Suruí e tinha quarenta índios. No ano anterior eles eram 126, em uma semana perderam dois terços da população. Então eu encontrei um povo traumatizado, desesperado, tanto é que em Índios e Castanheiros, no nosso 
primeiro Prefácio, a gente falava no final dos índios, como se não houvesse saída. Havia uma grande apatia, um desespero. Então a gente viu que tinha que ter também uma ação indigenista. Veio a ditadura, mas assim mesmo a gente dava entrevista em jornal, fazia críticas. Não era muito fácil, mas a gente conseguia sempre fazer alguma coisa, a ABA era muito presente. A minha história com a política indigenista começa com o SPI, mas em 1967 o SPI deixa de existir e surge a FUNAI e, de certa forma, eu já estava participando, porque para o primeiro Conselho Indigenista o CNPq indicou o Roberto Cardoso de Oliveira como membro e eu como suplente.

Campos: No período do SPI?

Roque Laraia: No SPI eu nunca tive contato direto. Mesmo porque o SPI estava acabando em um mar de corrupção. É preciso lembrar o seguinte: o Roberto, o Darcy e o Galvão estiveram no SPI na década de 1950. Quando eles saíram do Museu do Índio, eles se dividiram. O Darcy foi para o CBPE (Centro Brasileiro de Pesquisas Educacionais), o Roberto foi para o Museu Nacional e o Galvão foi para o Museu Goeldi, em Belém. Então eles já haviam feito uma tentativa de trabalhar com o órgão indigenista, que não deu certo naquela época. Quando surgiu a FUNAI parecia uma coisa nova, uma tábua de salvação. Afinal, quem tinha feito todo o projeto da FUNAI era a Heloísa Alberto Torres - alguém precisava fazer uma tese sobre ela, é a primeira antropóloga brasileira, ela fez pesquisa de campo em 1928. A FUNAI foi criada e não tinha presidente, tinha o Conselho Indigenista, que era um órgão colegiado, e o secretário do Conselho era, de certa forma, o executivo da FUNAI. Isso foi no tempo em que o Ministro do Interior era o General Albuquerque. Mas o primeiro ato do General Costa Cavalcanti, o novo Ministro do Interior, foi desmembrar o Conselho e nomear um presidente. Bom, não acabou o Conselho, mudou, mas o Conselho todo pediu demissão. Nem todo mundo era antropólogo, mas eram pessoas que tinham conhecimento da questão indigenista. Aí então montaram um novo Conselho com pessoas muito ilustres, como Manuel Dieguez, Maria Beltrão e Marília Alvim, mas que não tinham familiaridade com a política indigenista. As pessoas que tinham tido mais contato com índios tinham visto índios mortos, eram os arqueólogos e os antropólogos físicos. Até que em 1974 o General Ismart assumiu a FUNAI e eu fui convidado a participar do Conselho. Fiquei no Conselho em dois mandatos: de 1974 a 1978 e de 1979 a 1982. Não há dúvida, hoje todo mundo diz isso, o melhor presidente que a FUNAI já teve foi o General Ismart. Tinha muito dinheiro, a revolução estava do lado dele. Foi nesta época que o Ministro do Interior lançou o projeto de emancipação dos índios. O que o General Ismart 
fez? Ele convocou uma reunião do Conselho para votar o projeto de emancipação, convocaram uns cinqüenta antropólogos para assistir à reunião e aí o Conselho votou contra o projeto. $\mathrm{O}$ projeto era, aparentemente, muito bom. Foi aí que nós aprendemos que antropólogo não pode ler projeto sem ter um advogado do lado. Foi a partir daí que o Silvio Coelho resolveu fazer aquelas reuniões sobre Antropologia e Direito. Os textos da lei são escritos de uma maneira que leigos como a gente só vêem a coisa boa, não vêem o que está por trás. O que ia acontecer se os índios fossem emancipados é que a terra ia ser dividida em lotes individuais, qualquer um compraria aqueles lotes, passar-se-ia a ter direito de vender. Iríamos ter um monte de bóias-frias. Bom, mas eu queria voltar à pergunta.

Campos: A pergunta era sobre a comparação entre a FUNAI do passado e a dos anos recentes. Roque Laraia: É um pouco diferente. A FUNAI no período do General Ismart tinha liberdade para trabalhar, não era refém dos índios, raramente se via índios na FUNAI. Mas o que está acontecendo recentemente.... Eu, conhecendo a FUNAI há tantos anos, não tinha a ilusão de que seria um trabalho fácil. Quando apareceu um nome como o do Carlos Frederico Marés para ser o presidente, com um ministro como o J osé Carlos Dias, dizendo que ia dar todo o apoio necessário... O Marés me convidou (eu já tinha sido convidado pelo Márcio Santilli, que queria criar uma Diretoria de Pesquisa e Documentação e eu ocuparia esta Diretoria, que incluía a área de pesquisa do Museu do Índio) e eu acabei na Diretoria de Assuntos Fundiários, que cuida do controle da terra, que é a principal questão dos índios. Mas, nestes nove meses, as condições de trabalho foram muito difíceis. O presidente da FUNAI não faz nada a não ser ouvir, é o dia inteiro, das sete horas da manhã às nove, dez horas da noite só ouvindo. Os Xavante principalmente, em segundo lugar os Fulniô. Das 210 sociedades indígenas, pode saber que as que vão à FUNAI não chegam a dez. Katukina jamais aparece lá. São só dez: Kayapó, Xavante, Fulniô, Pataxó, os índios do Nordeste de um modo geral, Pankararu. É uma pressão para cima do presidente, são todas reivindicações individuais, raramente há uma reivindicação coletiva. Com exceção dos Kayapó, que nunca pedem nada que não seja coletivamente. Desse jeito não há condição de trabalhar, porque o papel do presidente é um papel político, ele tem que correr atrás de dinheiro, de recurso, de coisa desse tipo. Em segundo lugar, não tem dinheiro. O orçamento da FUNAl é R\$ 140 milhões, dos quais quase $\mathrm{R} \$ 100$ milhões estão comprometidos com a folha de pagamento. Aí você pensa: tem funcionário demais. Tem, mas está tudo aposentado, funcionários na ativa são dois mil e cem, 
mais quatrocentos DAS, somam dois mil e quinhentos. Pode-se pensar que é muita gente, mas são 570 terras indígenas espalhadas pelo Brasil inteiro, com dimensões territoriais equivalentes a duas Franças, são 100 milhões de hectares. O país tem 850 milhões de hectares, as terras indígenas são 100 milhões. Então duas mil e quinhentas pessoas não é nada. Se você pegar o Vale do J avari, são 8 milhões de quilômetros quadrados. Se tiver cinco funcionários lá é muito. Destes dois mil e quinhentos funcionários tem que tirar o pessoal da sede e do Museu do Índio. Então, não tem gente. Logo que assumimos, constatei: são três ou quatro crises por dia. Crise assim: "estão matando, fulano morreu, mataram um funcionário". A FUNAI hoje tem uma taxa de mortalidade em serviço que o Exército brasileiro não tem. O Exército não entra em guerra desde 1945. Todo ano a FUNAI tem funcionário assassinado e, principalmente, funcionário que morreu de malária, de doenças tropicais. Então há um pessoal desmotivado, com salários baixos e despreparados. Antigamente os funcionários eram preparados, foi o General Ismart quem criou os cursos de indigenismo de que os funcionários participavam. Agora não tem mais nada disso. Aqueles famosos sertanistas não existem mais, no máximo são meia dúzia. Eu falei para o Marés: "Vamos criar uma sala da crise", como o Pentágono, o presidente teria à disposição sete ou oito sertanistas experimentados para auxiliá-lo, mas não tem gente para fazer isso. Não há vontade política de resolver a questão. A dívida fundiária da FUNAl é de $\mathrm{R} \$ 200$ milhões. A rubrica, no ano 2000, para pagar essa dívida foi de $\mathrm{R} \$ 4$ milhões.

Campos: E o que compõe essa dívida?

Roque Laraia: Pela Constituição de 1988, quando se demarca uma terra indígena, é necessário pagar as benfeitorias de boa fé. O que é uma benfeitoria de boa fé? É uma construção que foi feita sem que se soubesse que era terra de índio. A pessoa ocupou a terra sem saber que era terra de índio. Não se pode pagar indenização da terra, porque a terra é do índio, é terra federal e não pode ser indenizada, mas as pessoas têm direito à indenização pelas benfeitorias. Tanto é que na Diretoria de Assuntos Fundiários tem o Departamento Fundiário e a função dele é enviar técnicos para fazer o levantamento dos custos destas benfeitorias. Logo depois daquela confusão em Porto Seguro, os Truká voltaram para suas terras, não queriam mais esperar o pagamento das indenizações e derrubaram umas torres de transmissão de energia. Essas torres abasteciam uma comunidade pequena de produtores agrícolas, umas quatorze mil pessoas, que ficaram sem luz e perderam toda a safra de frutas, na região do vale do São Francisco. Então telefonou um funcionário 
da Presidência da República, da Comissão da presidência da República sobre reassentamentos de gente que foi prejudicada pela construção de barragens, essas coisas, e falou: "A FUNAI não cumpre os seus prazos". Eu respondi: "Não, a FUNAI está rigorosamente dentro dos prazos. A dívida é de $\mathrm{R} \$ 200$ milhões, eu recebi $\mathrm{R} \$ 4$ milhões neste ano. Então eu tenho cinqüenta anos para pagar". O que acontece é isso: a FUNAI homologa as terras - e ela tem sido muito competente para isso, de 1988 para cá a FUNAI homologou 70\% das terras demarcadas -, os índios ficam sabendo que a terra foi homologada e os ocupantes da terra não saem. Não saem por quê? Porque só saem quando receberem o dinheiro. Quase sempre os ocupantes são pequenos produtores, posseiros. Os fazendeiros estão em algumas áreas e só. No Nordeste, por exemplo, são quase todos posseiros. São miseráveis que ficam quinze anos aguardando a indenização. Como acontece no caso dos Kiriri. Os Kiriri conseguiram jogar os posseiros para fora da terra, eles estão numa cidadezinha próxima. Eles ficam encostados na cidade, esperando há quinze anos a indenização que não passa de três ou quatro mil reais. Porque a benfeitoria deles era uma casinha de palha, uma coisa muito vagabunda. Aí chega um ponto em que os dois entram em conflito, os índios vão lá e matam e eles matam os índios. Quando você vai ao Ministro ou ao Presidente da República e fala em R\$ 200 milhões, ouve: "Poxa, mas isso não é dinheiro para o país". Não é, mas não sai o dinheiro nunca. Antes de eu sair da FUNAI, a gente pediu uma verba suplementar de $\mathrm{R} \$ 80$ milhões. Não saiu. Se sair agora, em dezembro, não interessa mais. Se sai uma verba de R\$ 80 milhões para você gastar até 31 de dezembro, não vai gastar e vai ter que devolver o dinheiro. Realmente é uma situação muito difícil. Porque no fundo você é pressionado pelos índios e a pressão deles seria justa se eles deixassem o pessoal trabalhar, mas não deixam. Quando eu saí da FUNAl eu pensei: passei quase quarenta anos defendendo os índios e teve dias lá em que eu estive a ponto de me atracar com os índios! Os Xavante, por exemplo, não admitem que mulher ocupe cargo de direção na FUNAI. O Marés nomeou a Suzana Grilo Guimarães como Diretora de Assistência. Os Xavante passaram a pressioná-la, dando bordunadas na porta da Diretoria...porque ela é mulher, é pequenininha. Então, todos os dias são de doze a quatorze horas enfrentando os índios e os papéis se acumulando em cima da mesa.

Campos: Nestes nove meses em que o senhor esteve na FUNAI, os Suruí ou os Assurini encaminharam alguma reivindicação?

Roque Laraia: Nunca. Isso é o que eu falo. Das 210 sociedades indígenas, 200 sociedades não vão 
à FUNAI. Os Suruí, eu tenho absoluta certeza de que eles sabiam que eu estava na FUNAI. Nunca me telefonaram. Então não são todos os grupos indígenas, são determinados grupos que têm uma reivindicação de terra inesgotável.

Campos: Em termos nacionais, qual seria o pior estado na proporção índio/terra?

Roque Laraia: O Mato Grosso do Sul é um barril de pólvora. Os Kaiová, os Terena e os Kadiveo não vão a Brasília, mas têm muitos problemas. A situação Kaiová e Terena é a seguinte: eles tiveram terras demarcadas na época do Rondon e naquela época a idéia era de que os índios iriam ser integrados, iriam desaparecer como índios, transformar-se em camponeses. Então fizeram pequenas reservas, geralmente reservas geométricas, quadradinhas, acreditando que os índios iriam para cidade (como, de fato, alguns foram), mas essas populações cresceram. Cresceram muito, a tal ponto que a maior aldeia do Brasil está em Dourados: a periferia da cidade de Dourados é uma aldeia que tem doze mil índios. Poucas sociedades indígenas brasileiras têm doze mil índios. Em todo lugar a população indígena cresceu, mas lá cresceu mais. O fato é que no Mato Grosso do Sul os índios estão asfixiados. O Getúlio Vargas fez uma reforma agrária lá, é a Colônia Agrícola de Dourados. Pegou todos os Guarani que estavam na região e pôs num cantinho. É uma situação muito difícil. Foram trinta e oito famílias brancas que receberam terra do estado em 1944, e os índios agora reocuparam as terras. As benfeitorias são caríssimas, porque embora fossem trinta e oito famílias de pequenos produtores, a terra é de primeiríssima qualidade, eles se capitalizaram e fizeram grandes benfeitorias. Uma delas é uma usina de beneficiamento de leite. A FUNAI não tem dinheiro para pagar isso e eles estão dentro da área, eles têm capacidade de recrutar apoio político e com argumentos difíceis de responder. O cara diz: "eu poderia até aceitar a indenização, mas aquela árvore lá, foi meu avô que plantou". É o mesmo discurso do índio. O professor Antônio Brant, da UFMS, fez uma tese de doutorado sobre as antigas terras dos Guarani. Esta tese contém um mapa. Os índios já têm uma cópia. As reocupações que estão acontecendo são exatamente nestas terras. Propusemos uma solução ao Marés: se toda aquela região do estado era Guarani, por que demarcar exatamente no ponto reocupado? O dinheiro que seria gasto com as indenizações poderia ser utilizado para comprar um pedaço de terra muito maior para esse grupo. Mas aí tem o seguinte: a FUNAI tem delegação para demarcar, mas não para comprar, mesmo porque a hora em que a FUNAI comprar terra, a porta no dia seguinte vai ter uma fila de quinhentos índios pedindo o mesmo tratamento. Veja a questão dos Fulniô. Os Fulniô invadiram um lugar lá, fora da área 
demarcada, e queriam que a FUNAI comprasse aquela terra, porque de lá qualquer um pode enxergar o ritual deles, um ritual secreto. Poder olhar, pode, mas é de longe, não vai escutar nada.

Campos: Pela experiência que o senhor teve agora na FUNAI, há alguma coisa que aponte para uma possível solução para esse estado de coisas?

Roque Laraia: Eu brincava lá que a primeira coisa era mudar a presidência da FUNAI para Fernando de Noronha. Só assim o presidente poderia trabalhar tranqüilamente.

Campos: A discussão do novo Estatuto do Índio, de alguma maneira, aponta para algum tipo de mecanismo que ajude a solucionar esse tipo de demanda ou é preciso rediscutir questões que estão na geração desse tipo de problema?

Roque Laraia: Eu realmente não sei. Outro dia eu dei uma entrevista para um jornal eletrônico da UNICAMP chamado Com-ciência e aí disseram que a Dominique Gallois acha melhor acabar com a FUNAI, que é um órgão falido. Eu tenho ouvido há décadas essa história de acabar com a FUNAI e entregar para a sociedade civil. Eu realmente não sei como é que a coisa fica se tirar o braço do Estado. Se você vê o discurso de Roraima, que é um caso-limite, é o discurso contra as organizações não-governamentais, a igreja católica e contra a FUNAI. O que eles dizem em Roraima? É que as organizações não-governamentais são sempre estrangeiras, a igreja católica é sempre estrangeira (os padres em Roraima são italianos, austríacos, quase não há padres brasileiros lá) e que a FUNAl é controlada pelo G7, pelas sete potências. É uma teoria da conspiração e o objetivo seria tomar a Amazônia. No caso de Roraima é mais específico, eles falam que todos querem fechar a fronteira Norte do mapa do estado com terras indígenas, e que já está faltando só um pedacinho. Quando fechar toda a fronteira com terras indígenas, o plano é fazer um país novo. É uma idéia generalizada que o prefeito de Normandia (que fica na fronteira de Roraima com a Guiana e a Venezuela) divulga. Na semana em que houve aquela confusão em Porto Seguro, o presidente da República mandou uma comissão para ver a situação em Raposa Terra do Sol. Convidaram o Marés para ir e ele me mandou no lugar dele. Eu fiquei hospedado no quartel do Exército. Raposa Terra do Sol é um dos lugares mais lindos que já vi na minha vida, é impressionante. O prefeito de Normandia começou a acusar a FUNAI na minha frente. Chegou ao ponto que eu falei para ele: "em primeiro lugar, nunca fui de nenhuma ONG. Em segundo, não tenho nenhum compromisso com a igreja católica ou com qualquer outra religião. E, em terceiro lugar, não admito que o senhor venha a duvidar da lealdade que tenho com meu país. Então não venha me acusar de coisas desse tipo". O prefeito me pediu 
então mais de quinhentas desculpas. Como você vai pensar numa agência de proteção aos índios que não seja um braço do Estado? Porque eu acho que muita gente ainda não invadiu terra porque acredita que a FUNAI ainda tem alguma força. O Estado em algum momento não vai faltar. Quando, em 1944, no massacre dos Krahô, o Estado foi lá, demarcou mais terras e prendeu gente. É uma utopia imaginar que a sociedade civil vai tomar conta dos índios. Fazem parte da sociedade civil os garimpeiros, os fazendeiros, os posseiros, os sem-terra, todos. Tudo isso faz parte da sociedade civil ou a sociedade civil somos só nós, os antropólogos? Eu acho que o problema tem de ser repensado. Eu não sei se esta centralização absurda que existe hoje é a solução. Quando foi presidente da FUNAI, o Sidney Possuelo acabou com as delegacias regionais. Então você tem 52 administrações conectadas diretamente na presidência. Antes havia os anteparos, os problemas eram filtrado antes de chegarem até Brasília. Não existe mais isso.

Até aqui eu falei apenas de uma parte, que é a parte fundiária. A FUNAl tem três diretorias: uma não interessa que é a Administrativa, as outras diretorias são a Fundiária e a de Assistência. A Diretoria de Assistência foi enormemente esvaziada quando se passou a educação para o MEC e a saúde para o Ministério da Saúde. De qualquer forma, a FUNAI continua com a competência para cobrar. Na Diretoria de Assistência tem também os projetos de produtividade. Tem grupos indígenas que, com pouco dinheiro, o retorno é muito grande. Os Macuxi, de Raposa Terra do Sol, com pouco dinheiro vão conseguir produzir para encher Roraima de comida. Nessa viagem que eu fiz havia muita fartura, há terra boa e existe conhecimento para produzir. Mas eles ainda não têm o que precisam. Quando se divide esse dinheiro tem que pensar que, tirando o pessoal, a FUNAI trabalha com $\mathrm{R} \$ 40$ milhões, é muito pouco. Agora se você joga isso na lógica do governo, da equipe econômica, é muito dinheiro, porque são trezentos e cinqüenta mil índios. Primeiro, que é um argumento difícil de defender: por que eles querem a terra se eles não usam?

Campos: Mas não é possível formar algum tipo de consenso?

Roque Laraia: A gente tem um texto constitucional que, de certa forma, faz com que o Brasil, junto com os Estados Unidos e o Canadá, sejam os três países da América que mais preservaram as terras indígenas. O Peru não tem nada disso. No Peru eles transformaram os índios em campesinos.

Campos: Mas houve uma época em que havia um certo consenso, existia um projeto sobre o que fazer para solucionar os problemas das populações indígenas. 
Roque Laraia: O projeto era sempre defender a terra. Porque naquela época de ocupação da Amazônia, todo mundo sabia que a situação mais urgente era defender a terra. O que aconteceu é que a terra foi preservada. Isso era uma coisa que eu vinha tentando dizer, a maior parte dos problemas atuais estão fora da Amazônia. A maior parte dos problemas vem do Nordeste. Se a FUNAI tivesse $R \$ 200$ milhões e pagasse toda a sua dívida, acredito que reduziria em $90 \%$ a margem de conflitos.

Campos: O consenso anteriormente foi estabelecido em torno da questão da demarcação das terras indígenas. Imaginando um cenário ideal, em que o problema da terra fosse resolvido e restassem todos os outros, como deveria ser hoje a ação indigenista gerida pelo Estado? O senhor acredita que é possível formar algum consenso na chamada "questão indígena", considerando a multiplicidade de organizações não-governamentais?

Roque Laraia: Eu acho muito difícil. A questão hoje do novo Estatuto do Índio é um exemplo. Eu não tive muito tempo para estudar o projeto, mas eu o li. Ele melhora enormemente o anterior, que é de 1973. Mas puseram na cabeça dos índios que o novo estatuto acaba com a tutela. A tutela já acabou. A Constituição de 1988 acabou com a tutela. Tem duas categorias de gente que não acredita que a tutela acabou: uma é formada pelos índios e a segunda é formada pelos advogados da FUNAI. Em uma audiência pública que ocorreu na Câmara dos Deputados, um Xavante falou: "nós queremos a tutela porque somos livres". Eles querem ser funcionários públicos, mas querem ser tutelados. Por outro lado, há uma quantidade enorme de lideranças que são a favor do novo Estatuto, que discutem, passaram uma semana em Brasília discutindo em regime de internato. Apresentaram algumas alternativas. Uma das hipóteses que o Márcio Santilli pensou foi colocar a sede da FUNAI em Manaus, com o seguinte argumento: a Amazônia é o lugar onde tem mais índios. Garanto que funcionaria melhor.

Campos: O senhor não acha que é a falta de um projeto que permite esse tipo de pressão sobre o órgão indigenista?

Roque Laraia: O que me assusta é fazer uma reunião com todas as organizações nãogovernamentais, acho que vamos ter que ficar anos discutindo. Eu confesso que não tenho solução. Eu acho o seguinte: sem vontade política por parte do governo para fazer uma outra coisa não é possível. O governo fala: "nós já demos essa terra toda, 12\% do território nacional para trezentos e cinqüenta mil índios". Na hora de soltar o dinheiro, não solta. Eu acredito que o projeto do 
Márcio Santilli de criar uma Agência Nacional do Índio e delegar a execução de projetos às organizações não-governamentais resolveria alguns problemas. Por que o ISA (Instituto Socioambiental) resolveu trabalhar no alto rio Negro? O alto rio Negro é muito bom. Primeiro porque a população é majoritariamente índia e você tem ali centenas de índios altamente escolarizados. A UFPA, na década de 1980, fez o famoso vestibular indígena. Há lugares em que se tiver uma agência regional oferecendo suporte, oferecendo recursos, desenvolvendo projetos e não tendo paternalismo, as coisas andam melhor. Dizem que o lugar mais fácil para a FUNAI trabalhar é no Acre. Porque a FUNAI entrou lá só em 1975 e os índios aprenderam a viver sem ela. Tem um grupo lá, acho que é o Ashaninka, que já comercializou um sabão ecológico, não sei o quê. Os outros não, dizem que não tem dinheiro porque a FUNAI não mandou. Eles partem do princípio que, além da terra, a FUNAI tem agora que mantê-los. Seria fácil manter se as demandas fossem as demandas tradicionais, mas não são. Os Kayapó pedem avião, viaturas, câmeras de vídeo, tudo isso. Porque os Kayapó tiveram aquela idade do ouro e o ouro acabou, os rios ficaram cheios de mercúrio e então o que estão fazendo agora? É a vez do mogno, com todo o discurso ecológico. No Acre acho que não tem esse ranço paternalista, desse cargo cult que foi. O funcionário da FUNAI chegava em alguns lugares e distribuía dois mil facões, quando tinha dinheiro para fazer isso.

Campos: O senhor comentou que, das 210 sociedades indígenas, só dez chegam até a FUNAI em Brasília para encaminhar suas reivindicações. O que faz a diferença?

Roque Laraia: Eu não saberia responder. Uma delas é a facilidade de acesso. Os Fulniô, se resolvem ir à FUNAI, eles reúnem de trinta a quarenta índios, fretam um ônibus e saem de Recife. São dois ou três dias de viagem, mas é só asfalto, chegam na FUNAl, apresentam a conta e vão para aquelas pensões. Os Xavante chegam a Brasília em dez horas, em Barra do Garça tem ônibus quase de hora em hora. Esse é um aspecto. Imagina quanto ia gastar o cara do Acre, em tempo e dinheiro, para chegar a Brasília! Mas eu não estou dizendo que esse é o único aspecto, porque um Suruí pode pegar um ônibus em Marabá e ir para Brasília com a maior facilidade. No entanto, não vai. Eu acho que é uma mentalidade que se criou de que se tem que viver às custas da FUNAI.

Campos: Apesar de todos esses problemas, o senhor acredita que ainda há espaço para a atuação de antropólogos na FUNAI?

Roque Laraia: Existe muito espaço para antropólogos na FUNAI. Existe um consenso dentro do 164 órgão de que faltam antropólogos na FUNAI, tanto dentro da Diretoria de Assuntos Fundiários 
como em outras unidades. As administrações da Amazônia, de Pernambuco, por exemplo, queixavam-se sistematicamente do fato de possuírem apenas uma antropóloga. É verdade que em alguns setores existe um preconceito contra os antropólogos, mas são casos isolados. Além disso, o espaço de trabalho deve ser conquistado. Um importante trabalho neste sentido foi feito pelos antropólogos mais antigos da casa. Uma coisa é certa: existe muito trabalho para antropólogos dentro da FUNAI.

Curitiba, 16 de novembro de 2000. 